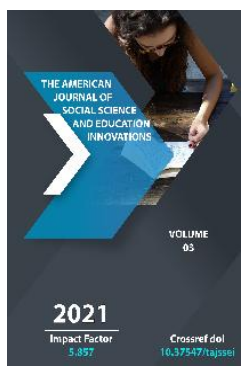

\title{
"Educational Infrastructure" Is An Important Factor Of The Beginning Of The Third Renaissance Period In Uzbekistan
}

\author{
Kamaldin Abzalovich Yunusov \\ Professor Of The Department Of Theory Of Civil Society Of Andizhan State University, Doctor of \\ Political Sciences, Andizhan Region, Republic Of Uzbekistan
}

Journal Website:

http://theamericanjour

nals.com/index.php/taj

ssei

Copyright: Original content from this work may be used under the terms of the creative commons attributes 4.0 licence.

\section{ABSTRACT}

In the state analysis "Infrastructure of education" as an important factor in the beginning of the third Renaissance in Uzbekistan in the conditions of modern globalization. It reflects the "Educational infrastructure" the basic concepts and practical results and proposals.

\section{KEYWORDS}

Globalization, the third Renaissance, state and national interests, the education system, educational infrastructure, national education, topical areas of science, specialties.

\section{INTRODUCTION}

In the modern process of the conditions of the globalization of the world, many developing countries, such as Uzbekistan, which has chosen the path of democratic development, are striving to reach the level of developed countries. This requires the modernization of the socio-economic life of society using the latest technologies. There is also a need to organize the management of socio-political, legal, educational and many other spheres on the basis of democratic principles based on a socially oriented market economy. Otherwise, 
the intended goal will not be achieved. Because just as it is impossible to build a modern rocket launcher based on the design of an old car, it is impossible to form the foundations of a democratic state and civil society based on the rule of law, with old socio-political views, attitudes and management methods (for example, command control).

\section{METHODS}

The ultimate goal of the radical reforms carried out in our country is to reach the level of developed countries and create a decent life for our people. The interests of the state and the people, patriotic education in the formation of a culture of serving the state and society, the beginning of the third revival in Uzbekistan and its prospects - all this is directly related to education, in particular with the development of higher education. When considering the education system in Uzbekistan as a whole, each of its links: preschool, general education, secondary specialized, higher and postgraduate education, as well as having its own important features that distinguish it from other structures, acts as a single system.

\section{RESULTS AND DISCUSSIONS}

The introduction of innovation, especially in higher education, will ultimately lead to significant changes in all other areas of education. Thus, the introduction of innovation and investment in higher education is an important factor in the beginning of the third revival in Uzbekistan. The slogan "New Uzbekistan, new worldview" includes exactly this. Speaking at the ceremony dedicated to the Day of Teachers and Trainers on October 1 , 2020, President Shavkat Mirziyoyev said: "Science, education and upbringing are the cornerstone of development and strength that makes a country strong and a nation great. It is no coincidence that the bright future of our country is closely connected, first of all, with the education system and upbringing of our children"[1].

Therefore, the upbringing, education and upbringing of a harmoniously developed generation, perfectly developed in all respects, remains one of the most important tasks of our state. Therefore, today in our country serious attention is paid to the human factor. The human factor, its duty in society, attention to rights and freedoms, interests are considered as the main and main direction of further deepening democracy and forming the foundations of civil society in Uzbekistan.

The decree of the President of the Republic of Uzbekistan dated October 8, 2019 "On approval of the Concept for the development of the higher education system of the Republic of Uzbekistan until 2030" is of great practical, theoretical and historical significance [2]. The document sets the task of radical reform of higher education, comprehensive improvement of the system for training qualified specialists in accordance with the country's development strategy, organization of training modern bachelors and masters on the basis of international requirements. Higher education is a key factor in determining the future development of the country, playing a critical role in reforming all aspects of civil society. Therefore, the training of competitive, highly qualified personnel in the labor market, a radical improvement in the quality and efficiency of the higher education system is the main basis of the social policy of each country [4].

In the Address of the President of the Republic of Uzbekistan to the Oliy Majlis of January 24, 2020, 2020 is declared the Year of Science, Education and Development of the 
Digital Economy. This general concept of development has a direct impact on all levels of education, especially the higher education system.

In the field of education, in particular in higher education, it is advisable to strengthen mutual competition, to reduce the dependence of state universities (universities) on the state budget. In turn, it is possible to organize branches of universities in developed countries in each region of the country (initially as an experiment in one or several regions). They need to train professionals in modern, market-oriented areas that are the most vulnerable in our economy.

It is advisable to create an "Educational Infrastructure" in each region. What is educational infrastructure? "Educational infrastructure" - includes educational institutions located in a certain area, and related facilities. The concept of "educational infrastructure" is a concept close to such concepts as "university town", "Student town", which still exist in Tashkent and are called.

The concept of "educational infrastructure" corresponds to the concept of "educational campus", enshrined in the Law of the Republic of Uzbekistan "On Education" dated September 23, 2020 No.637. The law defines the educational town as follows: "integrated educational buildings, research institutes (centers), production complexes and technology parks, temporary accommodation of participants in the educational process, laboratories, information resource centers (libraries), sports facilities, general educational environment, consisting of a complex of buildings and structures, including public catering facilities, ensuring high efficiency of the educational process, spiritual and moral education" [3].
On the territory of the "Educational Infrastructure", there will be a branch of the university of a developed foreign country, as well as, preschool educational institution with in-depth study of foreign languages (English, Russian, Korean, Japanese, etc.), primary school (4 years), in accordance with with the specialties of the university, there is a complex of a general education school, a secondary specialized educational institution (lyceum, 2 years of study) with in-depth study of individual disciplines. Curricula for the disciplines taught in the above-mentioned educational institutions are developed on a competitive basis by professors of the highest category and their teachers and approved by the relevant ministries, and the educational process is organized on their basis.

Every five years, all teachers of the abovementioned educational institutions improve their qualifications in a foreign country. It is also desirable to build an "educational infrastructure" on the basis of an equal partnership at the expense of local public and private entrepreneurs. In other words, the funds of private entrepreneurs will be used to invest in the construction of "educational infrastructure", and the profit will be returned in the form of dividends. In this regard, it is very important to conduct propaganda work among influential entrepreneurs, to treat them on the basis of democratic principles, without using violence against them. When building an "educational infrastructure", it is necessary to take into account the specifics of the region in the field of production, its prospects and resources.

\section{CONCLUSION}

The following conclusions should be drawn from the above opinions and comments. 
1. Construction of "educational infrastructure" is an important impetus to strengthening the innovative environment in education in Uzbekistan.

2. Investments in the construction of "educational infrastructure" - an important basis for the start of the third revival in Uzbekistan.

3. Creation of "educational infrastructure" in general, sharply exacerbates competition at all levels of education, between public educational institutions and private education, especially among teachers (because of their attitude to work, demand for their knowledge, between salaries) and in others relations, of course, there will be a significant difference).

4. After graduation from the "Educational Infrastructure", young men and women from Uzbekistan with higher education and certain specialties will be employed, first of all, in our country and abroad. Most importantly, they work in other countries not as laborers (migrant black jobs), but as mature professionals in their respective fields. Uzbeks working abroad bring home hard currency and investment in education.

5. After graduation from the "Educational Infrastructure" young people with higher education and individual specialties will become an important impetus for the development of the country's economy.

6. "Educational infrastructure" has many other advantages in the development of the country, which we will discuss in our next articles.

\section{REFERENCES}

1. Sh.M. Mirziyoyev. Teachers and trainers are our great strength, support and backbone in building a new Uzbekistan. Speech by the President of the Republic of
Uzbekistan Sh.M. Mirziyoyev at the ceremony dedicated to the Day of Teachers and Trainers // "Khalk suzi", October 1, 2020.

2. Decree of the President of the Republic of Uzbekistan Sh.M. Mirziyoyev "On approval of the Concept for the development of the higher education system of the Republic of Uzbekistan until 2030".

https://uza.uz/oz/documents/zbekistonrespublikasi-oliy-talim-tizimini-2030yilgacha-riv-09-10-2019.

3. "Law on Education of the Republic of Uzbekistan" // "Khalk Suzi" newspaper. From 24.09.2020.

4. Abrorov I. The system of higher education is developing on the basis of modern approaches. Popular performance, April 26, 2017 